\title{
Problems and Solutions for Local College Constructing Resource Sharing Courses
}

\author{
Chunyan Wu \\ Jilin Agricultural University Office of Academic Affairs Jilin Changchun
}

Keywords: Local colleges; Resource sharing course construction; Problems and solutions

\begin{abstract}
The continuous development of social economy has provided good opportunities for the development of education career, and at the same time puts forward higher requirement. Under this environment, the education career is also going through reform so as to be adapted to the requirement to the time. The college resource sharing curriculum construction is an important part of college education informationalization and is also an effective part to improve the education quality, and meanwhile provides a new opportunity to improve teaching quality after enrollment expansion. At present, there are problems in terms of college network teaching, remaining to be discussed about. This paper mainly introduces the current condition of college resource sharing curriculum construction, and analyzes problems in the process, and suggests measures, hoping to help this construction.

Network education is a totally new teaching mode, which is changing into a social practical activity when the informationization is strengthening and is beneficial to improve teaching mode. The digitalization and network direction will become the inevitable trend of education, which can effectively improve the education quality, cultivate the comprehensive quality of students, become an important part of education reform adapted to social development and has a critical effect on improving college education. Therefore, we should focus on network teaching to innovate and improve the development of education career in China.
\end{abstract}

In October 12, 2011, the Ministry of Education issued Implementation views to construct excellent and open courses to firstly clear excellent open courses, including public open courses and excellent resource sharing. It is aimed to popularize excellent courses and can demonstrate modern education philosophy and teaching rules, advanced teaching methods to serve learners. In May 21, 2012, the Ministry of Education issued Implementation methods to share excellent courses to construct excellent courses and clear its targets. What's more, it also began to organize and implement excellent courses, which are important parts of teaching reform and can be considered as important platforms to improve education innovation and deepen teaching reform. At the same time, they can also highlight running philosophy, course features, teaching quality etc, which are important channels to improve high quality talents. To conclude, excellent course sharing construction has become a major topic and direction of higher education in the education field.

Excellent courses sharing takes college teachers and students as main bodies, which at the same time can be beckoned as the basic courses to help change the teaching philosophy, lead the reform of teaching contents as well as teaching methods. What's more, based on various information technology, excellent courses sharing can realize college resource sharing to further improve the quality of talents and construct learning-inclined society.

\section{The Necessity for Local Colleges to Construct Courses Sharing}

As the main part of China's higher education system, local colleges and universities aim to serve the region's economic and social development to train high-quality talents for local areas. However, due to funding sources, quality of students, there is a gap between resource construction, curriculum construction, personnel training etc comparing to affiliated colleges. So, it is really difficult to well implement it and cover a wide range. What's more, even comprehensive colleges built by several colleges, they cannot cover all running condition. Besides, schools have their own features and differences in terms of professional structure, teacher quality and students capacity. Based on this, there is definitely a big difference among course organization and profession cultivation. Therefore, 
course sharing can be considered as an important channel to realize resources complementary, and mutual benefit. Through curriculum resources opening and interaction, we can avoid duplication of curriculum resources and unnecessary waste of money, improve teacher's teaching quality to drive the comprehensive development, which has critical meaning to improve the harmonious and sustainable development of higher education in China.

\section{Main Contents for College Network Resource Construction}

Teaching resources refer to various resources to support teaching activities, which can be objectively existing forms or real objects to attain the goal of teaching. Network teaching resources include a series of contents and it is hard to give a simple definition, the network resources we talk in this paper refer to resources which can be run in the network and can help to carry out teaching activities. College Network teaching resources include resources platform construction and general teaching resource construction, showing in the following aspects: (1) teaching resource sharing platform. This is an important part of teaching resources, teachers can communicate on a platform to improve their teaching skills. (2) instructional materials library. It contains media and text information, which is deemed as the school of knowledge, including teaching materials, teaching exercises, teaching materials and other content, while teachers can find the information they need inside the library to enrich the teaching contents and improve teaching quality. (3) teaching website. Teaching Web site helps teachers find out more information about current events to enhance students' awareness of history and time. Students can learn through the website to improve the efficiency of learning. (4) digital library. The item helps both teachers and students, you can get more information. (5) application software. Software is an effective means to use computer networks, and once you master the software, you can better take advantage of network technology.

\section{Problems When Local Colleges Construct Resource Sharing Courses}

With the development of network technology, teaching informationization has become an inevitable trend of teaching reform. Network resource teaching is an important part of Informationization teaching, which plays an important role in teaching, and continues to dig into the potential of network teaching. However, there are many issues remaining to be considered, because there are fewer excellent courses, which has seriously affected the quality of network teaching. Main problems are showing in the following:

Not Enough Attention to Resource Sharing Courses. The development efficiency of course resources has become a new challenge faced by local colleges while lots of local colleges should pay more attention to this and there is no overall plan with random decisions. In most cases, it is carried out by superior order and teachers implement it in a hurry without a clear mind. In addition, the course construction quality is remaining to be improved.

The Basic Infrastructure of Local Colleges Cannot Meet the Demand of Resource Sharing Course Teaching. At present, local colleges are generally weak in in terms of the basic infrastructure construction for network teaching, showing in capitals and technology. In terms of capitals, they only have single support and they don't put enough money into it which cannot meet the demand of informationization. In terms of technology, computer network technology is continually improving which asks higher demand on network teaching while the equipment of these local colleges cannot meet the development of times and they have to invest money to update these equipment.

In Shortage of Professional Human Resources and Poor Courses. While constructing resource sharing courses, colleges pay more attention to hardware and invest more energy and money on resources configuration to create enough resources for network and machine, ignoring software resources. Therefore, there are shortages in terms of system application, resource management and personal education. Especially, trainings in terms of resource sharing course construction, development process and software application for teachers are not in time, which will affect the construction quality and confine the application. 
Network Resource Construction Is not Scientific, and There Are Repeated Resource Developments. During popular global MOOC construction process, local colleges also carry out network resources courses construction and various colleges have invested both human resources and material resources since the education department implemented measures. However, in fact, most of the online platforms are not applied frequently and have poor effect besides some famous universities. The resource sharing construction should be completed by a lot of people, while different people have different minds without a standard, so it will bring about difficulties. At the same time, network resource construction lacks coordination and the sharing mechanism cannot be realized. What's more, every school has a set of network resource facility, which will bring about

Teachers Are Not Highly Motivated in Construction While Schools Give Limited Support. A high quality resource sharing course asks higher demand on the profession of teachers. In terms of content, it has to cover the basic content, principles methods, research tools, typical case and frontier of course, which should also be scientific and attractive. In terms of resources, it asks abundant teaching resources, including basic documents, such as syllabi, teaching calendar, lecture notes, videos, literature resources, test to realize open sharing. For an ordinary teacher, he has to contribute a great deal of time and effort to complete the task with the support of technical team. At present, besides heavy teaching task, they have to undertake research pressure, daily affairs and social service responsibility. It is difficult to undertake the responsibility of implementing resource sharing because they only have limited funds, they contribute their passion to do it, and it cannot develop sustainably without the support of capitals.

\section{Measures to Improve the Effect for Local Colleges to Construct Resource Sharing Courses}

Colleges Should Make Reasonable Plan to Scientifically Develop the Construction of Resource Sharing Course. Local colleges should look ahead to construct resources sharing curriculum and carry out proper plan based on reality. It should also take it as an integral part of the school curriculum, clear the quantity and quality goals, determine both the responsibility as well as the limitations of organization and management institutions to gradually establish a guarantee system and realize the goals.

Strengthen the Construction on Network Teaching Resource Equipment. Development of network teaching in colleges needs infrastructure support, therefore we have to strengthen the construction of infrastructure. Local colleges should raise funds from multiple sources, increase funding for infrastructure, constantly update technology to adapt to the needs of the times. Meanwhile, schools should also take the initiative to innovate based on practice and build resources according to reality to finally improve the education quality.

Strengthen Training on Teachers and Technical Stuff. The development of resource sharing course needs support from a teaching group which needs rich experience in terms of course construction and teaching management. In addition, a professional information team is also needed to complete high quality tasks. In conclusion, we have to strengthen the construction of these two teams to achieve the goal with half the effort and meanwhile improve the course quality.

Scientifically Implement Network Resource Construction and Avoid Repeated Resource Development. Currently, colleges are closely related to each other while some of them set a course union such as Tsinghua School, course sharing allay among western and eastern colleges, local MOOC ally etc, which help to establish a bridge between colleges and society to exchange ideas and knowledge. Colleges share their advanced courses while students also share excellent teaching resources. Based on this, both colleges and students can improve themselves. However, colleges have to carry out coordination to implement with a clear purpose so as to avoid repeated resource development and realize resource sharing, which can save a series of human and material resources.

Establish Incentives and Guarantee the Quality of Course Development and Application. Resource sharing course development requires a lot of time and effort, and teachers participated in the process have to be respected and encouraged. Colleges should formulate relative incentives such as subsidies and bonus. In addition, they should also carry out appraisal through comparison so as to encourage teachers to contribute themselves into the course sharing development and enrich 
curriculum resources.

\section{Acknowledgements}

Jilin Education Science Twelfth five-year Planning theme 'Study on the practice of local agricultural colleges' courses improvement under the environment of transformation of higher education' (No: ZD15053)

\section{References}

[1] Ministry of Education. Implementation views to construct excellent and open courses to firstly clear excellent open courses (Ministry of Education, [2011]8))

[2] Ministry of Education. Implementation methods to construct excellent course resource sharing(Ministry of Education, [2012]2))

[3] Xm Lv and Yf Jiang: Consideration and countermeasures to construct college network resource sharing [J]. Journal of Changshu Institute of Technology, ,(2010)No3,p.126

[4] Ld Feng: Discuss on the sustainable development policies for excellent course sharing of higher vocational school [J]. China Adult Education, (2014)No11,p.84

[5] Fm Qiu: Reflections and practice on constructing excellent course sharing for higher vocational schools- from the perspective of evaluation index system[J] vocational and technical education,(2013)No29,p.30

[6] Cy Wang: Construction and practice for excellent course sharing construction based on application-oriented talent training- Take Introduction of Tourism as example[J]. Journal of Guangxi College of Education(2015)No5,p.132

[7] Li Hu: Study on the policies for excellent course sharing construction [J]. Journal of Distance Education(2012) No 6,p.80 